\title{
Pleiotropic functions of the transmembrane domain 6 of human melanocortin-4 receptor
}

\author{
Hui Huang and Ya-Xiong Tao \\ Department of Anatomy, Physiology and Pharmacology, College of Veterinary Medicine, Auburn University, 212 Greene Hall, Auburn, Alabama 36849, USA \\ (Correspondence should be addressed to Y-X Tao; Email: taoyaxi@ auburn.edu)
}

\begin{abstract}
The melanocortin-4 receptor (MC4R) is a critical regulator of energy homeostasis and has emerged as a premier target for obesity treatment. Numerous mutations in transmembrane domain 6 (TM6) of MC4R resulting in functional alterations have been identified in obese patients. Several mutagenesis studies also provided some data suggesting the importance of this domain in receptor function. To gain a better understanding of the structure-function relationship of the receptor, we performed alanine-scanning mutagenesis in TM6 to determine the functions of side chains. Of the 31 residues, two were important for cell surface expression, five were indispensable for $\alpha$-melanocyte-stimulating hormone $(\alpha-\mathrm{MSH})$ and $\beta-\mathrm{MSH}$ binding, and six were important for signaling in the Gs-cAMP-PKA pathway. H264A, targeted normally to the plasma membrane, was undetectable by competitive binding assay and severely defective in basal and stimulated cAMP production and ERK1/2 phosphorylation. Nine mutants had decreased basal cAMP signaling. Seven mutants were constitutively active in cAMP signaling and their basal activities could be inhibited by two MC4R inverse agonists, Ipsen $5 \mathrm{i}$ and ML00253764. Five mutants were also constitutively active in the MAPK pathway with enhanced basal ERK1/2 phosphorylation. In summary, our study provided comprehensive data on the structure-function relationship of the TM6 of MC4R. We identified residues that are important for cell surface expression, ligand binding, cAMP generation, and residues for maintaining the WT receptor in active conformation. We also reported constitutive activation of the MAPK pathway and biased signaling. These data will be useful for rationally designing MC4R agonists and antagonists for treatment of eating disorders.
\end{abstract}

Journal of Molecular Endocrinology (2012) 49, 237-248

\section{Introduction}

The global epidemic of obesity, with a prevalence of $9.8 \%$ of adults worldwide (Kelly et al. 2008) and $33.8 \%$ of adults in the USA (Flegal et al. 2010), has become one of the most significant burdens to public health. Obesity is a major independent risk factor for cardiovascular diseases and is often associated with type 2 diabetes mellitus as well as other comorbidities (Guh et al. 2009). Though intervention of dietary control and physical activity can successfully contribute to the prevention of weight gain in some groups, it is difficult to reach long-term weight loss maintenance, especially for those carrying genetic alterations (Lemmens et al. 2008, Reinehr et al. 2009, Kraschnewski et al. 2010).

Multiple genes have been identified to be associated with obesity, and mutations in the melanocortin-4 receptor $(M C 4 R)$ have been characterized as the most frequent cause of monogenic obesity in humans, with a prevalence of from 0 to $6 \%$ in different ethnic backgrounds (reviewed in Tao (2010)). Therefore, the MC4R has emerged as a premier target for obesity treatment. Adopting a codominant inheritance model (O'Rahilly et al. 2003), MC4R pathogenic mutations exhibit a varied degree of penetrance, interacting with the environment (Stutzmann et al. 2008).
The MC4R, which is crucial for regulating both food intake and energy expenditure (Huszar et al. 1997), is a G protein-coupled receptor (GPCR) primarily expressed in the GNS. Although the classical G protein for MC4R is the Gs, recent studies suggested that MC4R couple to all three major classes of $\mathrm{G}$ proteins (reviewed in Breit et al. (2011)). The Gs-cAMP-PKA and ERK1/2 signaling pathways are of particular interest because they are identified to be related to the MC4R function of energy homeostasis in vivo (Sutton et al. 2005, Czyzyk et al. 2008).

Up to now, more than 150 naturally occurring mutations or common alleles of the MC4R have been identified (reviewed in Tao (2009)). They are scattered throughout the receptor, including transmembrane domain 6 (TM6). At least ten naturally occurring mutations or variants have been identified in TM6 and functionally characterized. Some of the mutants (such as L250Q, P260Q, F261S, and I269N) are retained in the endoplasmic reticulum (ER; Proneth et al. 2006, Xiang et al. 2006, Fan \& Tao 2009, Tan et al. 2009, Wang \& Tao 2011), and L250Q (Proneth et al. 2006, Xiang et al. 2006) and I251L (Xiang et al. 2006) are constitutively active. Most of these mutations are associated with obesity, whereas I251L confers strong protection from obesity (Stutzmann et al. 2007,

DOI: 10.1530/JME-12-0161 Online version via http://www.endocrinology-journals.org 
Mirshahi et al. 2011). During the past few years, several studies have demonstrated the functional importance of TM6 in the MC4R (Chen et al. 2007a,b, 2009).

Despite these important studies, no systematic investigation of the whole TM6 has been reported. To gain a better understanding of the structure-function relationship of the MC4R, we sought to determine the function of each residue in TM6 of the receptor using alanine-scanning mutagenesis. We generated 31 mutants and used the two endogenous ligands, $\alpha$-melanocyte-stimulating hormone $(\alpha-\mathrm{MSH})$ and $\beta-\mathrm{MSH}$, for ligand binding and signaling studies. We also studied the basal activities of the constitutively active mutants (CAMs) in the ERK1/2 signaling pathway.

\section{Materials and methods}

\section{Materials}

$\left[{ }^{125} \mathrm{I}\right]-\left[\mathrm{Nle}^{4}, \mathrm{D}-\mathrm{Phe}{ }^{7}\right]-\alpha-\mathrm{MSH}$ (NDP-MSH) was purchased from American Radiolabeled Chemicals (St Louis, MO, USA), $\alpha$-MSH from Pi Proteomics (Huntsville, AL, USA), and $\beta$-MSH from CHI Scientific (Maynard, MA, USA). ML00253764 and Ipsen 5i were synthesized by Enzo Life Sciences, Inc. (Plymouth Meeting, PA, USA). Radiolabeled cAMP was iodinated with chloramine $\mathrm{T}$ method. The c-myc-tagged WT hMC4R at the N-terminus was described previously (Tao \& Segaloff 2003).

\section{Site-directed mutagenesis}

Mutant receptors were generated by QuikChange site-directed mutagenesis kit (Stratagene, La Jolla, CA, USA) using the WT receptor as the template and sequenced by the DNA Sequencing Facility of University of Chicago Cancer Research Center (Chicago, IL, USA) to confirm the presence of desired mutations and the absence of errors in the coding sequences.

\section{Cell culture and transfection}

HEK293 and 293T cells were purchased from American Type Culture Collection (Manassas, VA, USA) and were cultured in DMEM with $10 \%$ newborn calf serum. The HEK293T cells were plated into six-well clusters coated with $0 \cdot 1 \%$ gelatin, transfected with the WT or mutant constructs at $50 \%$ confluence using calcium phosphate precipitation method (Tao et al. 2010), and were used for ligand binding and signaling studies $\sim 48 \mathrm{~h}$ later. For western blot, HEK293T were seeded into gelatincoated $100 \mathrm{~mm}$ dishes and were transfected using the same method. The transfected HEK293 cells were selected by G418 for imaging the cell surface expression by confocal microscopy.

\section{Ligand binding assays}

HEK293T cells were transfected as described earlier. On the day of experiment, cells were washed twice with warm Waymouth's MB752/1 media (Sigma-Aldrich) containing $1 \mathrm{mg} / \mathrm{ml} \mathrm{BSA} \mathrm{(Waymouth/BSA).} \mathrm{Then} \mathrm{cells}$ were incubated with $1 \mathrm{ml}$ Waymouth/BSA containing $50 \mu \mathrm{l}, 100000$ c.p.m. of ${ }^{125} \mathrm{I}-\mathrm{NDP}-\mathrm{MSH}$, and with or without different concentrations of $\alpha$ - or $\beta$-MSH giving a final concentration ranging from $10^{-10}$ to $10^{-5} \mathrm{M}$ for $1 \mathrm{~h}$ at $37^{\circ} \mathrm{C}$. Cells were then washed twice with cold Hank's balanced salt solution to terminate the reactions, lysed by $100 \mu \mathrm{l} 0.5 \mathrm{M} \mathrm{NaOH}$, collected with cotton swabs, and counted in a gamma counter.

\section{cAMP assay}

HEK293T cells were transfected as described earlier. On the day of experiment, cells were washed twice with warm Waymouth/BSA and then incubated with $1 \mathrm{ml}$ fresh Waymouth/BSA containing $0.5 \mathrm{mM}$ isobutylmethylxanthine (Sigma-Aldrich) for $15 \mathrm{~min}$ at $37^{\circ} \mathrm{C}$. Then cells were treated with or without different concentrations of $\alpha$ - or $\beta$-MSH giving a final concentration ranging from $10^{-11}$ to $10^{-5} \mathrm{M}$. After incubation at $37^{\circ} \mathrm{C}$ for $1 \mathrm{~h}$, cells were lysed by $0.5 \mathrm{M}$ perchloric acid containing $180 \mu \mathrm{g} / \mathrm{ml}$ theophylline and neutralized by $0.72 \mathrm{M} \mathrm{KOH} / 0.6 \mathrm{M}$ $\mathrm{KHCO}_{3}$. cAMP levels were measured using RIA (Fan et al. 2008, Tao et al. 2010).

\section{Confocal microscopy}

The method for immunohistochemistry (IH) has been described earlier (Tao \& Segaloff 2003). Briefly, HEK293 cells stably expressing c-myc-tagged WT or mutant hMC4Rs were established as described earlier. Cells were seeded into poly-D-lysine-coated eight-well chamber slides (Biocoat cellware from Falcon, BD Systems, Franklin Lakes, NJ, USA) and incubated at $37^{\circ} \mathrm{C}$ for $\sim 24 \mathrm{~h}$. Cells were fixed with $4 \%$ paraformaldehyde in filtered PBS for IH (PBS-IH) for $30 \mathrm{~min}$ and incubated with 5\% BSA in PBS-IH for $1 \mathrm{~h}$ to block nonspecific binding. Cells were then incubated with the primary antibody, 9E10 monoclonal anti-myc antibody (Developmental Studies Hybridoma Bank, the University of Iowa, Iowa City, IA, USA; 1:100 dilution in PBS-IH with $0.5 \%$ BSA) for $1 \mathrm{~h}$, and this was followed by incubation with the secondary antibody, Alexa Fluor 488-conjugated goat anti-mouse IgG (Invitrogen; 1:1000 dilution in PBS-IH $0.5 \%$ BSA) for $1 \mathrm{~h}$. The slide was then covered by a coverslip using Vectashield Mounting Media (Vector Laboratories, Burlingame, CA, USA). Fluorescent images were taken using a Bio-Rad confocal microscope. 


\section{Protein preparation and western blot}

HEK293T cells were seeded and transfected as described earlier. Approximately $24 \mathrm{~h}$ after transfection, cells were starved in Waymouth/BSA at $37^{\circ} \mathrm{C}$ overnight and then were treated with or without different concentrations of NDP-MSH giving a final concentration ranging from $10^{-9}$ to $10^{-6} \mathrm{M}$ in $5 \mathrm{ml}$ Waymouth/BSA for $5 \mathrm{~min}$ at $37^{\circ} \mathrm{C}$. Cells were placed directly on ice and washed twice with cold $0 \mathrm{G}$ (150 M NaCl and $20 \mathrm{mM}$ Hepes, $\mathrm{pH} 7 \cdot 4$ ) and then were scraped into lysis buffer in $0 \mathrm{G}$ (containing $0.5 \%$ NP-40, $2 \mathrm{mM}$ EDTA, $1 \mathrm{mM} \mathrm{Na} \mathrm{VO}_{4}$, and $1 \mathrm{mM}$ $\mathrm{NaF}$ ). Total protein concentrations were determined by Bradford protein assay, and $30 \mu \mathrm{g}$ protein samples were separated by $10 \%$ SDS-PAGE using the Trisglycine buffer system and blotted onto pre-wetted PVDF membranes in wet conditions. The membranes were blocked in $10 \%$ nonfat dry milk (containing $0 \cdot 2 \%$ Tween 20 ) for at least $3 \mathrm{~h}$ at room temperature with agitation and then immunoblotted with the primary antibodies, rabbit phosphorylation levels of ERK1/2 (p-ERK1/2) antibody (Cell Signaling, Billerica, MA, USA) 1:1000 and mouse $\beta$-tubulin antibody (Developmental Studies Hybridoma Bank, the University of Iowa) 1:40 000 diluted in TBST $/ 5 \%$ BSA overnight at $4^{\circ} \mathrm{C}$. This was followed by the incubation of the HRP-conjugated secondary antibodies, antirabbit IgG (Jackson ImmunoResearch, West Grove, PA, USA) 1:1000 and anti-mouse IgG (Jackson ImmunoResearch) 1:40 000 diluted in 10\% nonfat dry milk for at least $1 \mathrm{~h}$ at room temperature. Specific bands were detected with ECL reagent (Thermo Scientific, Rockford, IL, USA) and were analyzed and quantified by Image J Software (NIH, Bethesda, MD, USA).

\section{Statistical analysis}

The competitive binding curves and cAMP doseresponse curves were fitted to a one-site model using GraphPad Prism 4.0 Software (San Diego, CA, USA). Concentrations that result in $50 \%$ inhibition $\left(\mathrm{IC}_{50}\right)$ and apparent maximal binding $\left(B_{\max }\right)$ or receptor occupancy (Wang et al. 2008) were calculated from competitive binding data. Concentrations that result in $50 \%$ maximal responses $\left(\mathrm{EC}_{50}\right)$ and maximal responses $\left(R_{\max }\right)$ were calculated from cAMP assays. The significance of differences in p-ERK1/2 levels and binding and signaling parameters between WT and mutant hMC4Rs were analyzed by Student's $t$-test using Prism 4.0 Software.

\section{Results}

The two endogenous agonists of MC4R, $\alpha-\mathrm{MSH}$ (Fan et al. 1997) and $\beta$-MSH (Abbott et al. 2000), have been shown to be capable of controlling feeding and energy balance through activation of MC4R. Here, we first studied the binding and signaling properties of all 31 hMC4R mutants using $\alpha$ - or $\beta$-MSH as the ligand (Fig. 1).

\section{Pharmacology of the WT and mutant hMC4Rs at $\alpha-\mathrm{MSH}$}

Competitive binding assays were performed using ${ }^{125} \mathrm{I}-\mathrm{NDP}-\mathrm{MSH}$ as the radioligand, and different concentrations of $\alpha$-MSH, from $10^{-10}$ to $10^{-5} \mathrm{M}$, were used to displace radioligand in HEK293T cells transiently transfected with WT or mutant MC4Rs. IC $_{50}$ values were calculated and analyzed for the WT and mutant hMC4Rs. Our data showed that H264A had no detectable binding; L265A and Y268A had decreased

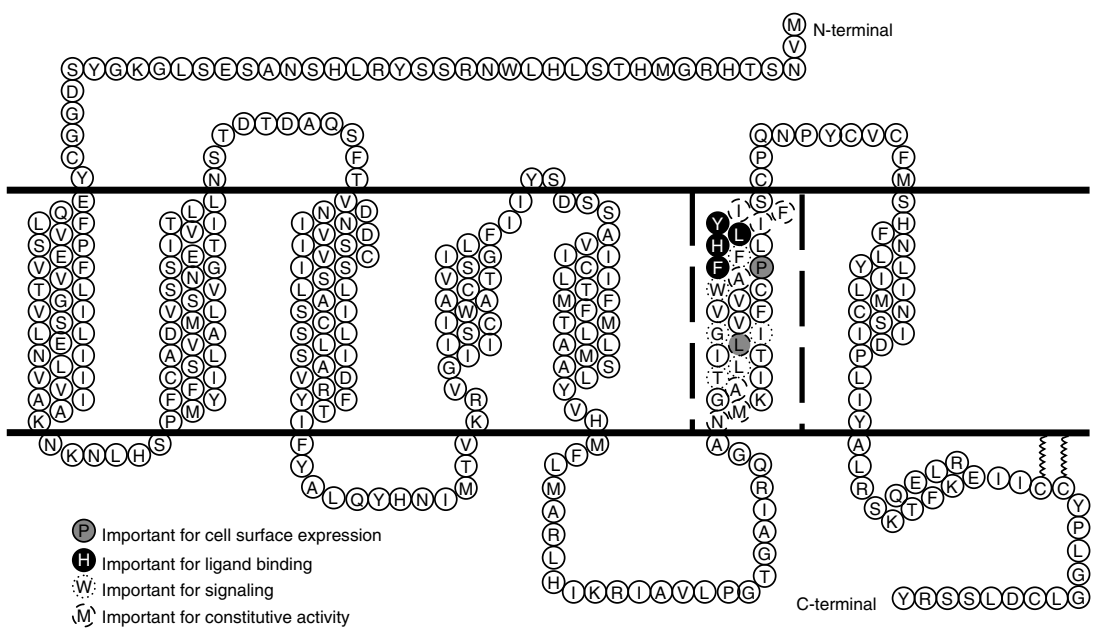

Figure 1 Schematic representation of the 31 residues in TM6 of hMC4R. The phenotypes of mutations at several loci that changed cell surface expression, ligand binding, signaling, and constitutive activity are highlighted. 

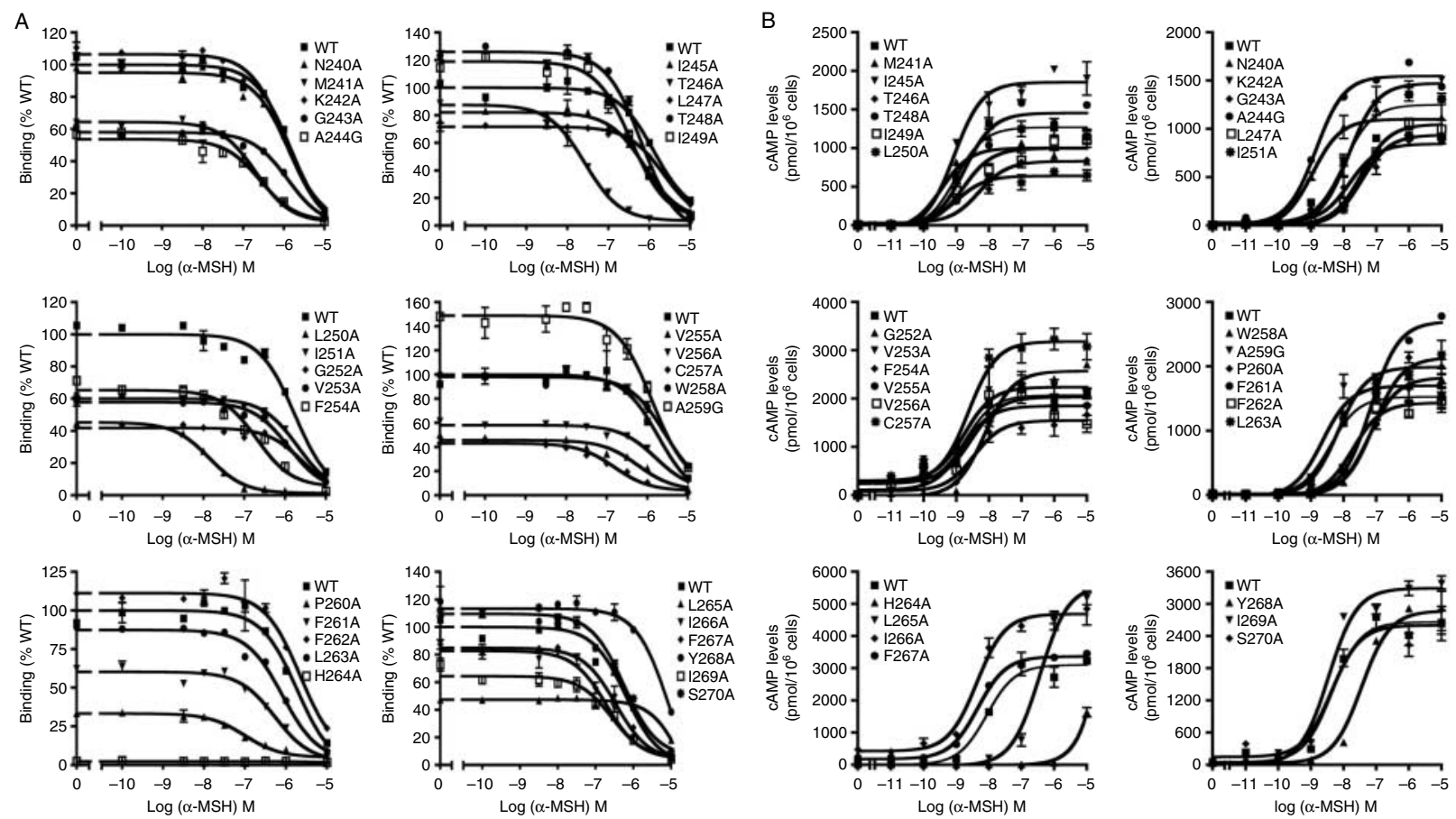

Figure 2 The ligand binding (A) and signaling (B) properties of WT and mutant hMC4Rs with $\alpha$-MSH as the ligand. HEK293T cells were transiently transfected with WT or mutant constructs, and $48 \mathrm{~h}$ later were used for binding and signaling studies. (A) Intact cell surface binding was measured by competitive inhibition of ${ }^{125}$ I-NDP-MSH with serial concentrations of $\alpha-\mathrm{MSH}$. Data are depicted as percentage of WT maximal binding. (B) Intracellular cAMP samples were collected with or without stimulation with different concentrations of $\alpha-\mathrm{MSH}$, and cAMP concentrations were determined by RIA. Data points are mean \pm S.E.M. of duplicate (A) or triplicate $(B)$ measurements within one experiment. Results are representative of at least three independent experiments.

affinities, whereas M241A, A244G, T246A, L250A, C257A, P260A, I266A, and F267A had increased affinities for $\alpha$-MSH (Fig. 2A and Table 1).

To measure the signaling capacities of the mutant receptors, HEK293T cells transiently transfected with WT or mutant hMC4Rs were stimulated with increasing concentrations of $\alpha$-MSH. Intracellular cAMP levels were measured after 1-h stimulation. Maximal response $\left(R_{\max }\right)$ and $\mathrm{EC}_{50}$ values were calculated from the doseresponse curves. Our data showed that H264A only responded to $10^{-5} \mathrm{M} \alpha$-MSH stimulation. Six mutants (L247A, W258A, P260A, F261A, L265A, and Y268A) had increased $\mathrm{EC}_{50}$ values compared with the WT hMC4R (Fig. 2B). One mutant (A259G) had decreased EC $_{50}$. Four mutants (G243A, T246A, L250A, and F254A) had decreased $R_{\text {max }}$, whereas five mutants (P260A, F261A, L265A, I266A, and I269A) had increased maximal responses compared with the WT hMC4R. The other mutants had similar $\mathrm{EC}_{50}$ and $R_{\max }$ as the WT hMC4R (Fig. 2B and Table 1).

\section{Pharmacology of the WT and mutant hMC4Rs at $\beta$-MSH}

When ligand binding and signaling experiments were performed using $\beta$-MSH as the ligand, similar data were obtained, with some moderate differences. In binding experiments, L265A and Y268A had significantly increased $\mathrm{IC}_{50} \mathrm{~s}$, whereas T246A, L250A, and P260A had decreased $\mathrm{IC}_{50} \mathrm{~s}$ (Fig. $3 \mathrm{~A}$ and Table 1). In signaling experiments, $\mathrm{H} 264 \mathrm{~A}$ was only responsive to $10^{-5} \mathrm{M} \beta-\mathrm{MSH}$ stimulation. Twelve mutants (T246A, L247A, L250A, I251A, G252A, F254A, W258A, P260A, F261A, F262A, L265A, and Y268A) had increased $\mathrm{EC}_{50} \mathrm{~s}$ compared with the WT hMC4R, and two mutants (V253A and A259G) had decreased $\mathrm{EC}_{50} \mathrm{~s}$ (Fig. 3B and Table 1). Three mutants (I245A, F254A, and A259G) had decreased $R_{\max }$ (Fig. 3B and Table 1).

$B_{\max }$ values were also calculated from these binding assays. As described earlier, H264A had no measurable binding. In addition, 12 mutants (G243A, A244G, L250A, I251A, F254A, V255A, C257A, P260A, F261A, L265A, I266A, and I269A) had decreased $B_{\max }$ (Fig. 4).

\section{Cell surface expression of several mutant hMC4Rs}

Retention of mutant receptors in the ER by the quality control system is the major defect of inactivating MC4R mutations (reviewed in Tao (2005)). For the six mutants (L250A, C257A, P260A, F261A, H264A, and 
Table 1 The ligand binding and signaling properties of WT and mutant hMC4Rs. Values are mean \pm S.E.M. of at least three independent experiments. The $R_{\max }$ of WT hMC4R was $2744 \cdot 11 \pm 373 \cdot 20 \mathrm{pmol} / 10^{6}$ cells with $\alpha$-MSH stimulation and was $2848 \cdot 15 \pm 377 \cdot 85 \mathrm{pmol} / 10^{6} \mathrm{cells}$ with $\beta$-MSH stimulation

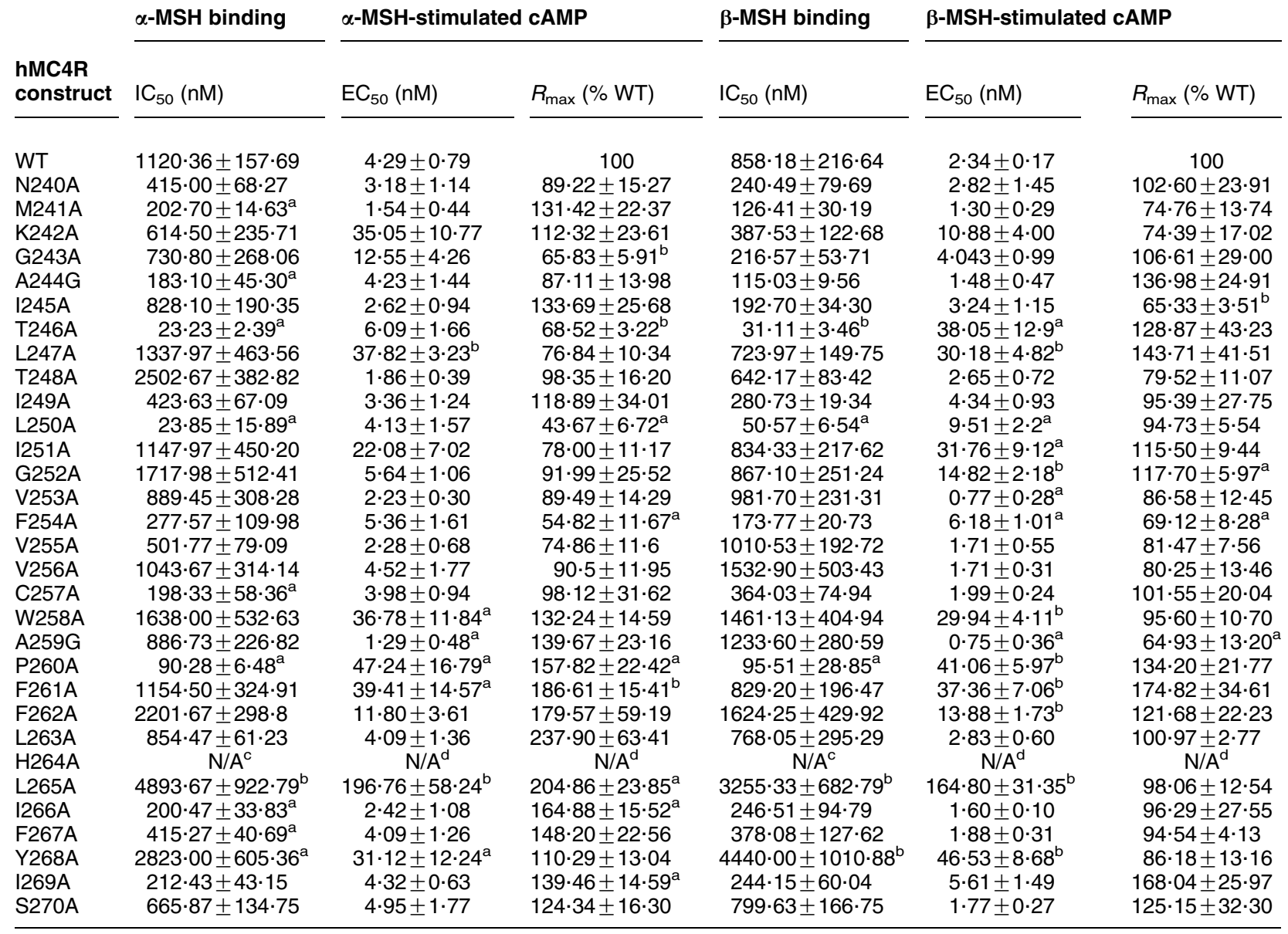

a Significantly different from WT hMC4R, $P<0.05$.

${ }^{\mathrm{b}}$ Significantly different from WT hMC4R, $P<0 \cdot 01$

cNot detected.

${ }^{\mathrm{d}}$ Only responsive to $10^{-5} \mathrm{M} \alpha$ - or $\beta$-MSH stimulation.

L265A) that caused dramatic decrease in $B_{\max }$, by more than 50\% of WT, F261A and H264A were previously reported to be targeted to the plasma membrane normally (Chen et al. 2007b, 2009), and L250A was described to be expressed at the cell surface at $57 \%$ of WT (Proneth et al. 2006). C257A showed increased affinity for ligand binding and normal signaling properties; therefore, it was not studied here.

We selected the two mutants (P260A and L265A) not studied before and one mutant (H264A) lacking ligand binding to investigate their expression at the plasma membrane. HEK293 cells stably expressing c-myc-tagged WT or mutant hMC4Rs were used and imaged by confocal microscopy at the nonpermeabilized status. Immunostaining of H264A and L265A was at least as strong as the WT hMC4R, demonstrating that the two mutants were indeed successfully transported to the plasma membrane. The immunostaining of P260A was weaker than that of the WT (Fig. 5).

\section{Constitutive activity of WT and mutant hMC4Rs in the cAMP pathway}

The MC4R was previously described to be constitutively active (Nijenhuis et al. 2001), and the extracellular $\mathrm{N}$-terminus of the receptor, which could be positioned similar to the endogenous agonists (Pogozheva et al. 2005), acted as a tethered intramolecular ligand (Srinivasan et al. 2004). Impairment in the fine-tuning of constitutive activity, the basal signaling in the absence of any ligand, was reported to affect the long-term energy balance (Srinivasan et al. 2004). Herein, the 

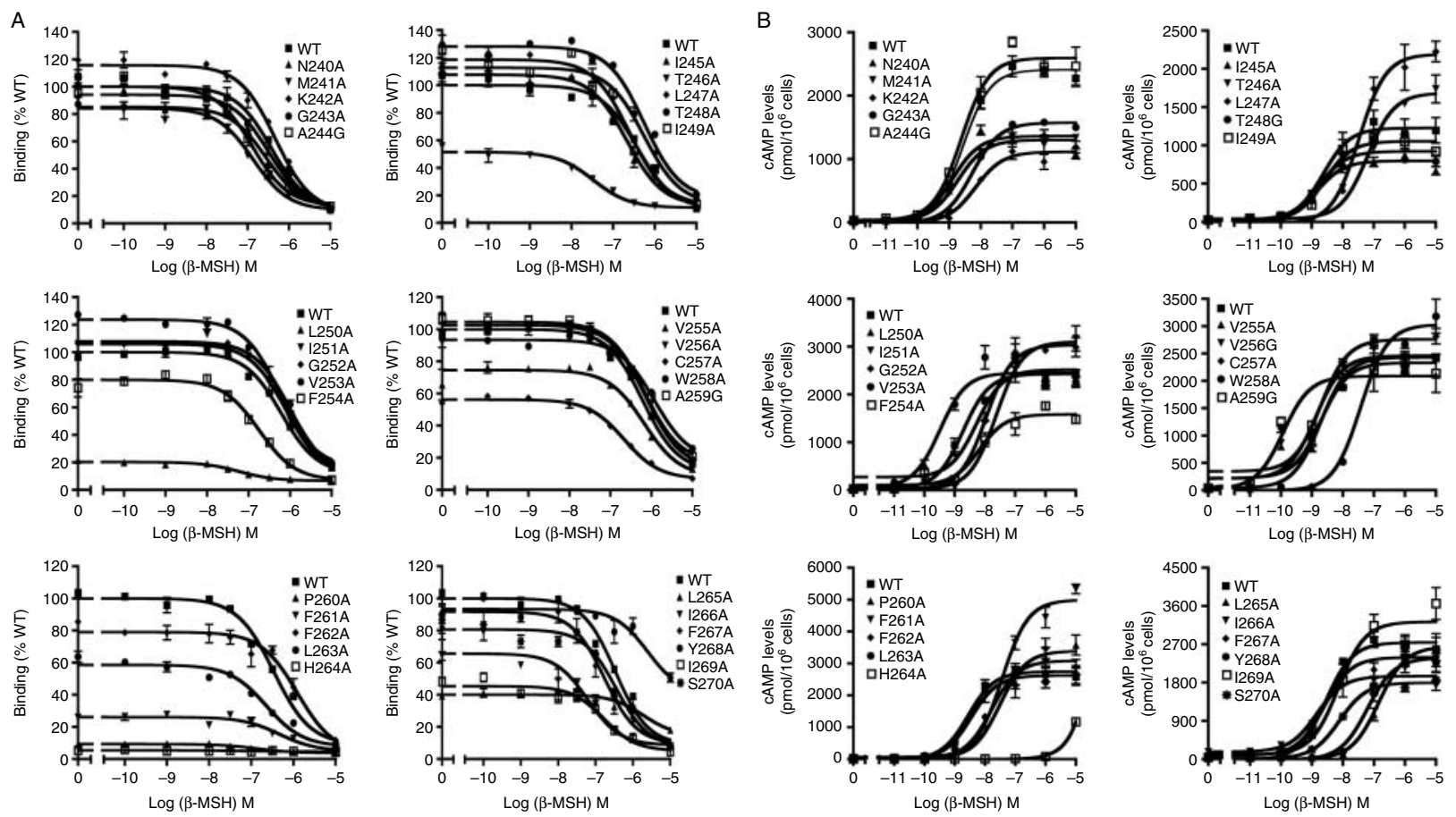

Figure 3 The ligand binding (A) and signaling (B) properties of WT and mutant hMC4Rs with $\beta$-MSH as the ligand. HEK293T cells were transiently transfected with WT or mutant constructs and $48 \mathrm{~h}$ later were used for binding and signaling studies. (A) Intact cell surface binding was measured by competitive inhibition of ${ }^{125} \mathrm{I}-\mathrm{NDP}-\mathrm{MSH}$ with serial concentrations of $\beta$-MSH. Data are depicted as percentage of WT maximal binding. (B) Intracellular cAMP samples were collected with or without stimulation with different concentrations of $\beta-\mathrm{MSH}$, and CAMP concentrations were determined by RIA. Data points are mean \pm s.E.M. of duplicate (A) or triplicate (B) measurements within one experiment. Results are representative of at least three independent experiments.

constitutive activities of the 31 mutants were measured and analyzed. The basal cAMP levels of the WT receptor were $32 \cdot 60 \pm 4 \cdot 39 \mathrm{pmol} / 10^{6}$ cells. We found that nine mutants (K242A, G243A, T246A, L247A, I251A, G252A, W258A, P260A, and H264A) had significantly lower basal cAMP levels compared with that of the WT receptor. Eight mutants (N240A, M241A, A244G, L250A, A259G, I266A, F267A, and I269A) displayed a modest elevation of basal activities and hence were identified to be CAMs (Fig. 6A).

Both Ipsen 5i (Ki $2 \mathrm{nM}$; Poitout et al. 2007) and ML00253764 (Ki $0 \cdot 16 \mu \mathrm{M}$; Vos et al. 2004) were synthesized and identified as selective antagonists of MC4R and subsequently were characterized to exert partial inverse agonistic actions at MC4R (Tao 2010, Tao et al. 2010). We studied the inverse agonistic properties of these two small molecules at the eight CAMs described earlier. HEK293T cells transiently transfected with WT or mutant hMC4Rs were incubated in the presence or absence of $10^{-6} \mathrm{M}$ Ipsen $5 \mathrm{i}$ or $10^{-5} \mathrm{M}$ ML00253764, and cAMP levels were measured. The basal activities of the WT and all the mutants were significantly decreased by the treatment of either Ipsen 5i or ML00253764. The maximal inhibition of L250A was $41 \%$ for Ipsen $5 \mathrm{i}$ and $60 \%$ for ML 00253764 . Of the WT and other mutants, the maximal inhibition ranged from 65 to $85 \%$ for Ipsen $5 \mathrm{i}$ and from 80 to $88 \%$ for ML00253764 (Fig. 6B).

\section{Constitutive activity of WT and mutant hMC4Rs in the ERK1/2 pathway}

MC4R activation results in phosphorylation of ERK1/2 (reviewed in Tao (2010)). We investigated whether seven mutant hMC4Rs that were constitutively active in cAMP pathway were also constitutively active in the ERK1/2 signaling pathway (N240A was not studied).

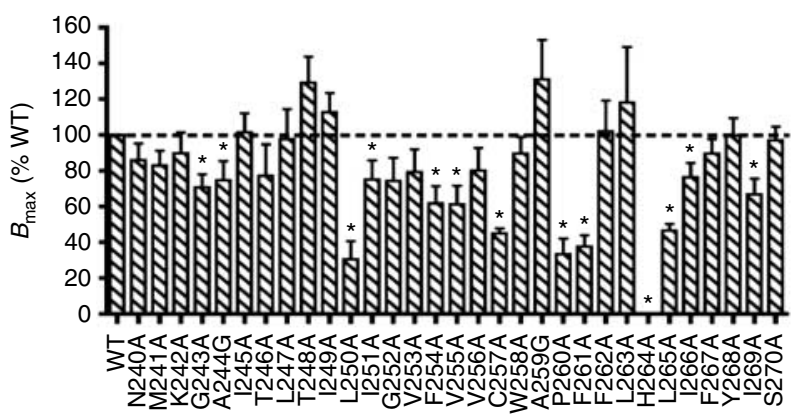

Figure 4 Total specific binding of WT and mutant hMC4Rs (\%WT). Data are mean \pm S.E.M. of at least six independent experiments. ${ }^{*}$ Significantly different from WT hMC4R, $P<0.05$. 

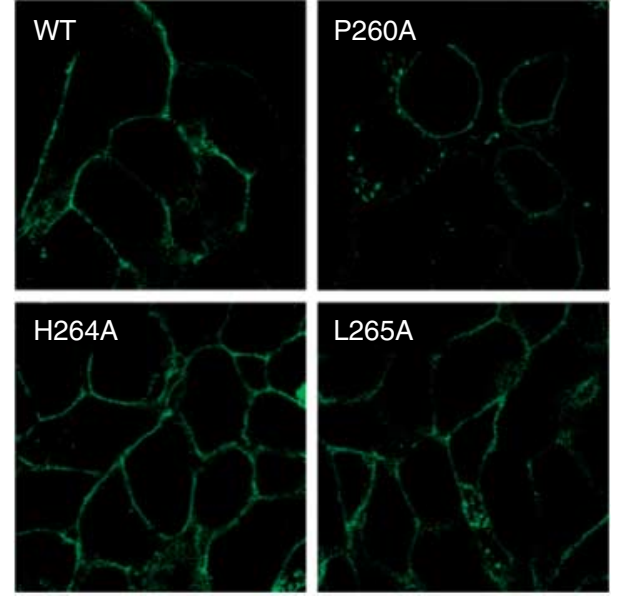

Figure 5 Confocal imaging of WT and mutant hMC4Rs. The intact HEK293 cells stably expressing WT or mutant receptors were stained with fluorescein-conjugated anti-myc monoclonal antibody and cell surface fluorescence were detected by confocal microscopy.

The p-ERK1/2 were measured through western blots. Data from the experiments showed that five of these mutants (M241A, L250A, I266A, F267A, and I269A) were also constitutively active in the MAPK pathway with significantly enhanced basal ERK1/2 phosphorylation. Two mutants (A244G and A259G) displayed similar basal p-ERK1/2 levels as the WT hMC4R (Fig. 7).

\section{Signaling property of H264A hMC4R in the ERK1/2 pathway}

H264A, undetectable in competitive binding assays, was only responsive to $10^{-5} \mathrm{M} \alpha$ - or $\beta$-MSH stimulation with increased cAMP production. One previous study reported that the $\mathrm{EC}_{50}$ of $\mathrm{H} 264 \mathrm{~A}$ was $0 \cdot 14 \mu \mathrm{M}$ for NDP-MSH (Chen et al. 2007b). To investigate whether it also affects the ERK1/2 signaling pathway, we studied p-ERK1/2 in the absence or presence of different concentrations of NDP-MSH, giving a final concentration ranging from $10^{-9}$ to $10^{-6} \mathrm{M}$. H264A was only responsive to $10^{-6} \mathrm{M}$ NDP-MSH stimulation. Compared with the WT hMC4R, H264A was significantly defective in both basal and stimulated ERK1/2 phosphorylation (Fig. 8).

\section{Discussion}

In rhodopsin-like GPCRs, TM6 has been demonstrated to be able to directly contact the ligand (Jaakola et al. 2008, Chien et al. 2010, Xu et al. 2011, Hanson et al. 2012), alter receptor conformations through intramolecular interactions (Palczewski et al. 2000, Park et al. 2008), and interact with cognate $\mathrm{G}$ proteins
(Abell \& Segaloff 1997, Murakami \& Kouyama 2008, Scheerer et al. 2008). In the $\beta_{2}$ adrenoceptor, TM6 has been shown to cause the largest changes between agonist- and inverse agonist-bound conformations (Rasmussen et al. 2007) and also been suggested to be involved in regulating the high basal activity of this receptor (Rasmussen et al. 2007, Rosenbaum et al. 2007). For the current study, we performed detailed pharmacological study of 31 alanine mutants of each residue in the TM6 of hMC4R.

Two residues (L250 and P260) were important for cell surface expression of hMC4R. Alanine mutations of the two residues (L250A and P260A) severely impaired normal plasma targeting of the receptor. At these positions, two naturally occurring mutations, L250Q (Proneth et al. 2006, Xiang et al. 2006) and P260Q (Wang \& Tao 2011), were also reported to cause intracellular retention of hMC4R, characterized by decreased cell surface expression but normal total expression levels. Further studies on the interactions between these mutants and molecular chaperones might help to understand the forward trafficking mechanism of MC4R. In the related MC3R, we showed that mutations at T280, corresponding to

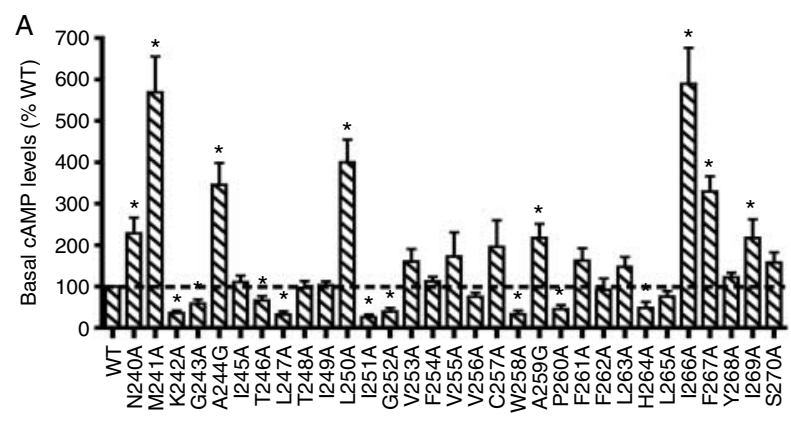

B

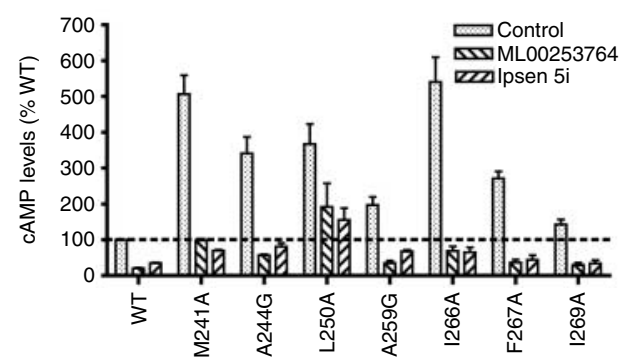

Figure 6 Basal activities of WT and mutant hMC4Rs. (A) HEK293T cells were transiently transfected with WT or mutant receptors and intracellular cAMP levels were measured without any stimulation of the ligand. Data expressed as percentage of WT basal activity are shown as mean \pm S.E.M. of at least six independent experiments. The cAMP levels of WT hMC4R were $32 \cdot 60 \pm 4 \cdot 39 \mathrm{pmol} / 10^{6}$ cells. *Significantly higher or lower than WT hMC4R, $P<0 \cdot 05$. (B) Partial inverse agonism of Ipsen $5 \mathrm{i}$ and ML00253764. HEK293T cells were transiently transfected with WT or mutant receptors, and $48 \mathrm{~h}$ later were treated with $10^{-6} \mathrm{M}$ Ipsen $5 \mathrm{i}$ or $10^{-5} \mathrm{M}$ ML00253764. cAMP levels were measured with RIA. 


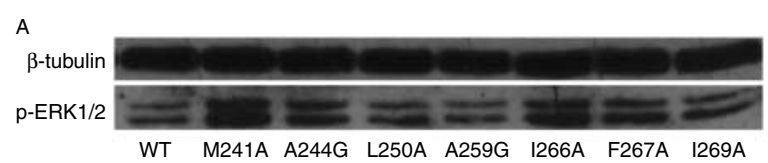

B

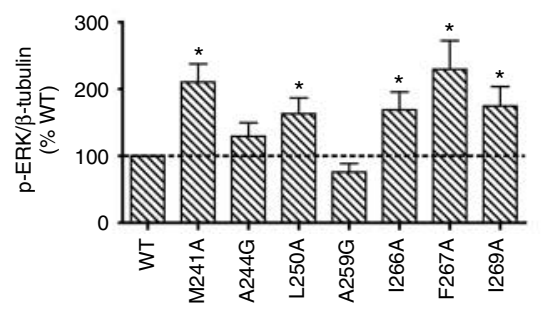

Figure 7 Constitutive activation of MAPK pathway. (A) HEK293T cells were transiently transfected with pcDNA 3.1, WT, or mutant hMC4Rs, and $24 \mathrm{~h}$ later cells were starved overnight and then harvested. Western blot analysis was performed using antibody against $p$-ERK $1 / 2$ and $\beta$-tubulin as a control. (B) Values are mean \pm S.E.M. of at least three independent experiments. *Significantly different from WT hMC4R, $P<0.05$.

T246 in the MC4R, decreased cell surface expression (Yang \& Tao 2012).

Five residues (F254, F261, H264, L265, and Y268) were indispensable for $\alpha$ - and $\beta$-MSH binding. F254 ${ }^{6.44} \mathrm{~A}$, which signaled normally with NDP-MSH stimulation (Chen et al. 2007b), had impaired interactions with $\alpha$ - and $\beta$-MSH. The corresponding residue of $\mathrm{Phe}^{6.44}$ in other GPCRs was reported to be important for the rotation of TM6, which led to an outward shift of the cytoplasmic end of this TM domain (Lebon et al. 2011, Rasmussen et al. 2011), and this movement opened the binding site for the carboxyl terminus of $\mathrm{G} \alpha$ (Scheerer et al. 2008). Previously, F261A and H264A were reported to severely impair the ligand binding and signaling processes of NDP-MSH (Yang et al. 2000, Haskell-Luevano et al. 2001, Chen et al. $2007 b$ ), though another study reported that F261A had no effect on NDP-MSH binding affinity but restored the signaling efficacy of modified NDP-MSH (Fleck et al. 2007). The residues important for the binding and signaling of $\alpha$ - and $\beta$-MSH are mostly located in the upper region of the TM domain. They probably could directly participate in the hydrophobic binding pocket (F261, H264, L265, and Y268) respectively, interacting with the pharmacophore $\mathrm{His}^{6}-\mathrm{Phe}^{7}-\mathrm{Arg}^{8}{ }^{8} \operatorname{Trp}^{9}$ of $\alpha$ - and $\beta-\mathrm{MSH}$.

Six residues (T246, L247, I251, G252, W258, and F262) were crucial for normal receptor signaling upon $\alpha$ - and $\beta$-MSH stimulation. Alanine mutations of these residues led to severely decreased signaling potencies and reduced basal signaling activities (except for F262A). These residues, primarily located at the cytoplasmic half of the TM domain, probably maintain the active conformation of the receptor. Serine mutation of G252 (G252S) caused significantly decreased signaling potency with $\alpha$-MSH and ACTH
(1-24) but not $\beta$-MSH (Xiang et al. 2007). However, alanine mutation of G252 (G252A) acted differently; it exhibited impaired signaling properties for both $\alpha$ - and $\beta$-MSH. W258A was previously reported to cause a threefold increase in $\mathrm{Ki}$ and $>10$-fold increase in $\mathrm{EC}_{50}$ with NDP-MSH stimulation by some studies (Chen et al. 2007b, 2009) and was described not to affect interactions with NDP-MSH by another study (Pogozheva et al. 2005). This mutant showed normal ligand binding but severe defect in signaling to $\alpha$ - and $\beta$-MSH in our study. The homologous residues of $\operatorname{Tr} p^{6.48}$ were described to directly contact with the ligand in $\mathrm{A}_{2 \mathrm{~A}}$ adenosine receptor (Jaakola et al. 2008) and rhodopsin (Cherezov et al. 2007) but not in $\beta_{2}$-adrenoceptor (Cherezov et al. 2007, Rasmussen et al. 2007).

Although no binding could be detected for H264A, with the more sensitive signaling assays, we showed that it responded to high concentrations of ligand stimulation with increased cAMP levels $\left(10^{-5} \mathrm{M} \alpha\right.$ - or $\beta$-MSH stimulation) and ERK1/2 phosphorylation $\left(10^{-6} \mathrm{M}\right.$ NDP-MSH stimulation). Basal signaling in both pathways was also decreased compared with the WT receptor. No apparent biased signaling (see below) was observed.

The basal activities of the MC4R have been suggested to be of physiological and pathophysiological significance. Defects in basal signaling have been suggested to be a potential cause of genetic obesity caused by MC4R mutations (Srinivasan et al. 2004). We also showed that some naturally occurring $M C 4 R$ mutations decrease basal signaling activity (Tao \& Segaloff 2005, Fan \& Tao 2009, Wang \& Tao 2011). Unlike the related MC3R that has no basal activity (Tao 2007), the WT hMC4R has modest basal activity that can be decreased by agouti-related protein (Nijenhuis et al. 2001,

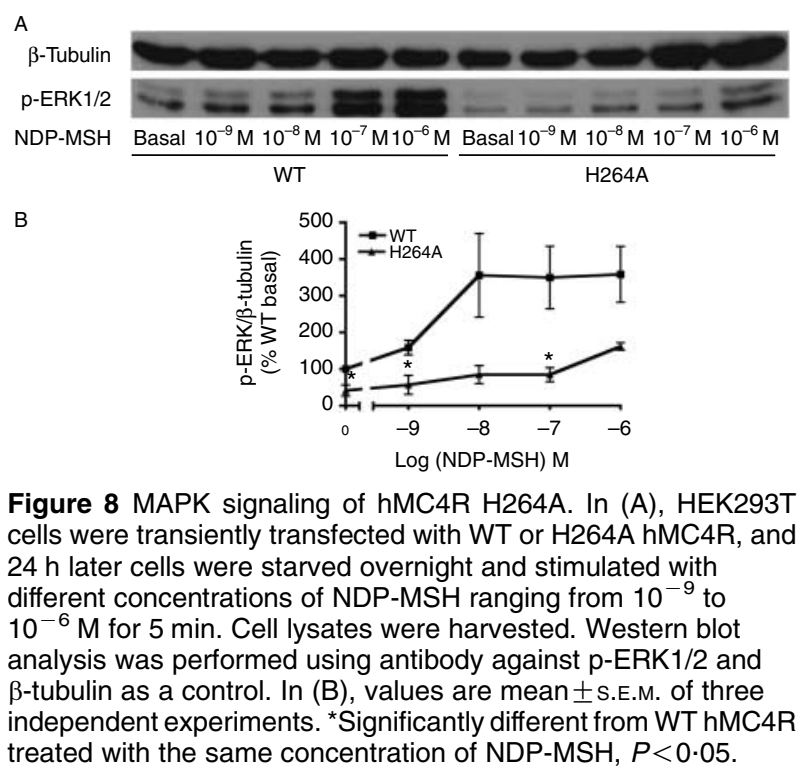

A $\mathrm{p}-\mathrm{ERK} 1 / 2$ NDP-MSH Basal $10^{-9} \mathrm{M} 10^{-8} \mathrm{M} 10^{-7} \mathrm{M} 10^{-6} \mathrm{M}$ Basal $10^{-9} \mathrm{M} 10^{-8} \mathrm{M} 10^{-7} \mathrm{M} 10^{-6} \mathrm{M}$

Figure 8 MAPK signaling of hMC4R H264A. In (A), HEK293T cells were transiently transfected with WT or H264A hMC4R, and $24 \mathrm{~h}$ later cells were starved overnight and stimulated with different concentrations of NDP-MSH ranging from $10^{-9}$ to $10^{-6} \mathrm{M}$ for $5 \mathrm{~min}$. Cell lysates were harvested. Western blot analysis was performed using antibody against $p$-ERK $1 / 2$ and independent experiments. * Significantly different from WT hMC4R treated with the same concentration of NDP-MSH, $P<0.05$. 
Tao et al. 2010). In this study, we showed that of the 31 mutations generated, nine mutants had significantly decreased basal activities (Fig. 6). Eight mutants (N240A, M241A, A244G, L250A, A259G, I266A, F267A, and I269A) had increased basal cAMP levels and the basal activities of these mutants could be partially inhibited by the treatment of either Ipsen $5 \mathrm{i}$ or ML00253764 (Fig. 6), two MC4R inverse agonists (Nicholson et al. 2006, Tao et al. 2010), suggesting that these mutants are CAMs. They are numbered as $6 \cdot 30$, $6 \cdot 31,6 \cdot 34,6 \cdot 40,6 \cdot 49,6 \cdot 56,6 \cdot 57$, and $6 \cdot 59$ according to the numbering scheme of Ballesteros \& Weinstein (Ballesteros \& Weinstein 1995). Previous studies with the glycoprotein hormone receptors showed that mutations at some of these loci (such as 6.30, 6.34, and $6 \cdot 40$ ) were found to cause constitutive activation that cause human diseases (reviewed in Tao (2008)). However, other loci found to cause constitutive activation in the glycoprotein hormone receptors, including the hotspot 6.44 and surrounding residues $6 \cdot 37,6 \cdot 38,6 \cdot 41,6 \cdot 42,6 \cdot 43$, and $6 \cdot 45$ (see Tao (2008) for original references), did not cause constitutive activation in hMC4R. These results suggested that although TM6 is a domain that is important for constraining the WT in inactive conformation in many GPCRs through interhelical interactions with TM5 and TM7 (Tao et al. 2002, Schneider et al. 2010), there are important differences in the local environment that contributed to the differences in constitutive activities.

It has been suggested that in family A GPCRs, an acidic residue at position 6.30 and R3.50 of the DRY motif in TM3 form a salt bridge constraining the WT receptor in inactive conformation. Mutations of $6 \cdot 30$ cause constitutive activation in rhodopsin (Ramon et al. 2007), $\beta_{2}$-adrenoceptor (Ballesteros et al. 2001), and lutropin receptor (Angelova et al. 2002). The salt bridge was indeed observed in the crystal structure of rhodopsin (Palczewski et al. 2000). However, the ionic lock is not observed in the crystal structures of the turkey $\beta_{1}$-adrenoceptor (Warne et al. 2008), the human $\beta_{2}$-adrenoceptor (Cherezov et al. 2007, Rosenbaum et al. 2007), human $\mathrm{A}_{2 \mathrm{~A}}$ adenosine receptor (Jaakola et al. 2008), and human $\kappa$-opioid receptor ( $\mathrm{Wu}$ et al. 2012). Mutagenesis data also suggested that this ionic lock is not important in other GPCRs (Schneider et al. 2010). N240 in hMC4R cannot form a salt bridge with R3.50, although its mutation led to constitutive activation.

MC4R also activates the ERK1/2 signaling pathway. We asked whether the mutants that had increased basal cAMP levels also constitutively activated the ERK1/2 pathway. Transfected cells were starved overnight in serum-free media and levels of phosphorylated ERK1/2 were measured by western blots. We showed herein that five of these mutants (M241A, L250A, I266A, F267A, and I269A) were also constitutively active in the MAPK pathway with significantly enhanced basal ERK1/2 phosphorylation. To the best of our knowledge, this is the first study to show that mutations in the MC4R could constitutively activate the ERK1/2 pathway. We showed that two mutants (A244G and A259G) had increased basal cAMP levels but had normal basal p-ERK1/2 levels. The results suggested that these mutants preferentially stabilize certain active conformations of the receptor. Mutations displaying biased signaling have already been identified in MC4R and several other GPCRs, such as MC4R-D90N (Buch et al. 2009), MC1R-E92K (Benned-Jensen et al. 2011), and $\mathrm{M}_{2}$ muscarinic acetylcholine receptor-Y104A and -Y177A (Gregory et al. 2010). Phosphorylation of ERK1/2 induced by MC4R has been described to be mediated by protein kinase A (Sutton et al. 2005), protein kinase C (Chai et al. 2006), or phosphoinositide 3-kinase (Vongs et al. 2004), depending on the cell lines used, and also may be initiated independently by $\beta$-arrestins as suggested in other GPCRs (reviewed in Violin \& Lefkowitz (2007) and Reiter et al. (2012)). More studies are needed to elucidate the biased signaling mechanisms of MC4R.

In summary, of the 31 residues in the TM6 of hMC4R, we have identified residues that were important for cell surface expression, ligand binding, cAMP production, and maintaining the $\mathrm{WT}$ receptor in active conformation. We also reported the constitutive activation of the ERK1/2 pathway. These data provided comprehensive information on the structure-function relationship of the TM6 of MC4R and will be useful for rationally designing MC4R agonists and antagonists for treatment of energy balance disorders.

\section{Declaration of interest}

The authors declare that there is no conflict of interest that could be perceived as prejudicing the impartiality of the research reported.

\section{Funding}

This study was supported by grants from the National Institutes of Health R15DK077213 and Animal Health and Disease Research Program and Interdisciplinary Grant of Auburn University College of Veterinary Medicine. The 9E10 c-myc antibody and E7 $\beta$-tubulin developed by $\mathrm{J}$ M Bishop and $\mathrm{M}$ Klymkowsky respectively were obtained from the Developmental Studies Hybridoma Bank developed under the auspices of the NICHD and maintained by Department of Biology, the University of Iowa, Iowa City, IA 52242, USA.

\section{Acknowledgements}

The authors thank Dr Zhenchuan Fan for generating the mutant constructs. 


\section{References}

Abbott CR, Rossi M, Kim M, AlAhmed SH, Taylor GM, Ghatei MA, Smith DM \& Bloom SR 2000 Investigation of the melanocyte stimulating hormones on food intake. Lack of evidence to support a role for the melanocortin-3-receptor. Brain Research 869 203-210. (doi:10.1016/S0006-8993(00)02386-6)

Abell AN \& Segaloff DL 1997 Evidence for the direct involvement of transmembrane region six of the lutropin/choriogonadotropin receptor in activating Gs. Journal of Biological Chemistry 272 14586-14591. (doi:10.1074/jbc.272.23.14586)

Angelova K, Fanelli F \& Puett D 2002 A model for constitutive lutropin receptor activation based on molecular simulation and engineered mutations in transmembrane helices 6 and 7 . Journal of Biological Chemistry 277 32202-32213. (doi:10.1074/ jbc.M203272200)

Ballesteros JA \& Weinstein H 1995 Integrated methods for the construction of three-dimensional models and computational probing of structure-function relations in $\mathrm{G}$ protein-coupled receptors. Methods in Neurosciences 25 366-428. (doi:10.1016/S10439471(05) 80049-7)

Ballesteros JA, Jensen AD, Liapakis G, Rasmussen SG, Shi L, Gether U $\&$ Javitch JA 2001 Activation of the $\beta_{2}$-adrenergic receptor involves disruption of an ionic lock between the cytoplasmic ends of transmembrane segments 3 and 6. Journal of Biological Chemistry 276 29171-29177. (doi:10.1074/jbc.M103747200)

Benned-Jensen T, Mokrosinski J \& Rosenkilde MM 2011 The E92K melanocortin 1 receptor mutant induces cAMP production and arrestin recruitment but not ERK activity indicating biased constitutive signaling. PLOS ONE 6 e24644. (doi:10.1371/journal. pone.0024644)

Breit A, Buch TR, Boekhoff I, Solinski HJ, Damm E \& Gudermann T 2011 Alternative $\mathrm{G}$ protein coupling and biased agonism: new insights into melanocortin-4 receptor signalling. Molecular and Cellular Endocrinology 331 232-240. (doi:10.1016/j.mce. 2010.07.007)

Buch TR, Heling D, Damm E, Gudermann T \& Breit A 2009 Pertussis toxin-sensitive signaling of melanocortin- 4 receptors in hypothalamic GT1-7 cells defines agouti-related protein as a biased agonist. Journal of Biological Chemistry 284 26411-26420. (doi:10.1074/jbc.M109.039339)

Chai B, Li JY, Zhang W, Newman E, Ammori J \& Mulholland MW 2006 Melanocortin-4 receptor-mediated inhibition of apoptosis in immortalized hypothalamic neurons via mitogen-activated protein kinase. Peptides 27 2846-2857. (doi:10.1016/j.peptides.2006.05.005)

Chen C, Jiang W, Tucci F, Tran JA, Fleck BA, Hoare SR, Joppa M, Markison S, Wen J, Sai Y et al. 2007a Discovery of 1-[2-[(1S)(3-dimethylaminopropionyl) amino-2-methylpropyl]-4-methylphenyl] -4-[(2R)-methyl-3-(4-chlorophenyl)-propionyl]piperazine as an orally active antagonist of the melanocortin- 4 receptor for the potential treatment of cachexia. Journal of Medicinal Chemistry $\mathbf{5 0}$ 5249-5252. (doi:10.1021/jm070806a)

Chen M, Cai M, Aprahamian CJ, Georgeson KE, Hruby V, Harmon CM \& Yang Y $2007 b$ Contribution of the conserved amino acids of the melanocortin-4 receptor in D-[Nle $\left.{ }^{4}, \mathrm{Phe}^{7}\right]-\alpha$-melanocyte-stimulating hormone binding and signaling. Journal of Biological Chemistry 282 21712-21719. (doi:10.1074/jbc.M702285200)

Chen M, Cai M, McPherson D, Hruby V, Harmon CM \& Yang Y 2009 Contribution of the transmembrane domain 6 of melanocortin- 4 receptor to peptide $\left[\mathrm{Pro}^{5}\right.$, DNal $\left.\left(2^{\prime}\right)^{8}\right]-\gamma-\mathrm{MSH}$ selectivity. Biochemical Pharmacology 77 114-124. (doi:10.1016/j.bcp.2008.09.023)

Cherezov V, Rosenbaum DM, Hanson MA, Rasmussen SG, Thian FS, Kobilka TS, Choi HJ, Kuhn P, Weis WI, Kobilka BK et al. 2007 Highresolution crystal structure of an engineered human $\beta_{2}$-adrenergic G protein-coupled receptor. Science 318 1258-1265. (doi:10.1126/ science.1150577)
Chien EY, Liu W, Zhao Q, Katritch V, Han GW, Hanson MA, Shi L, Newman AH, Javitch JA, Cherezov V et al. 2010 Structure of the human dopamine D3 receptor in complex with a D2/D3 selective antagonist. Science 330 1091-1095. (doi:10.1126/science.1197410)

Czyzyk TA, Sikorski MA, Yang L \& McKnight GS 2008 Disruption of the RIIbeta subunit of PKA reverses the obesity syndrome of agouti lethal yellow mice. PNAS 105 276-281. (doi:10.1073/pnas. 0710607105)

Fan ZC \& Tao YX 2009 Functional characterization and pharmacological rescue of melanocortin-4 receptor mutations identified from obese patients. Journal of Cellular and Molecular Medicine 13 3268-3282. (doi:10.1111/j.1582-4934.2009.00726.x)

Fan W, Boston BA, Kesterson RA, Hruby VJ \& Cone RD 1997 Role of melanocortinergic neurons in feeding and the agouti obesity syndrome. Nature 385 165-168. (doi:10.1038/385165a0)

Fan ZC, Sartin JL \& Tao YX 2008 Molecular cloning and pharmacological characterization of porcine melanocortin-3 receptor. Journal of Endocrinology 196 139-148. (doi:10.1677/JOE-07-0403)

Fleck BA, Ling N \& Chen C 2007 Substituted NDP-MSH peptides paired with mutant melanocortin- 4 receptors demonstrate the role of transmembrane 6 in receptor activation. Biochemistry 46 10473-10483. (doi:10.1021/bi700406k)

Flegal KM, Carroll MD, Ogden CL \& Curtin LR 2010 Prevalence and trends in obesity among US adults, 1999-2008. Journal of the American Medical Association 303 235-241. (doi:10.1001/jama. 2009.2014)

Gregory KJ, Hall NE, Tobin AB, Sexton PM \& Christopoulos A 2010 Identification of orthosteric and allosteric site mutations in M2 muscarinic acetylcholine receptors that contribute to ligandselective signaling bias. Journal of Biological Chemistry 285 7459-7474. (doi:10.1074/jbc.M109.094011)

Guh DP, Zhang W, Bansback N, Amarsi Z, Birmingham CL \& Anis AH 2009 The incidence of co-morbidities related to obesity and overweight: a systematic review and meta-analysis. BMC Public Health 9 88. (doi:10.1186/1471-2458-9-88)

Hanson MA, Roth CB, Jo E, Griffith MT, Scott FL, Reinhart G, Desale H, Clemons B, Cahalan SM, Schuerer SC et al. 2012 Crystal structure of a lipid G protein-coupled receptor. Science 335 851-855. (doi:10.1126/science.1215904)

Haskell-Luevano C, Cone RD, Monck EK \& Wan YP 2001 Structure activity studies of the melanocortin- 4 receptor by in vitro mutagenesis: identification of agouti-related protein (AGRP), melanocortin agonist and synthetic peptide antagonist interaction determinants. Biochemistry 40 6164-6179. (doi:10.1021/bi010025q)

Huszar D, Lynch CA, Fairchild-Huntress V, Dunmore JH, Fang Q, Berkemeier LR, Gu W, Kesterson RA, Boston BA, Cone RD et al. 1997 Targeted disruption of the melanocortin-4 receptor results in obesity in mice. Cell 88 131-141. (doi:10.1016/S0092-8674(00)81865-6)

Jaakola VP, Griffith MT, Hanson MA, Cherezov V, Chien EY, Lane JR, Ijzerman AP \& Stevens RC 2008 The 2.6 angstrom crystal structure of a human $\mathrm{A}_{2 \mathrm{~A}}$ adenosine receptor bound to an antagonist. Science 322 1211-1217. (doi:10.1126/science.1164772)

Kelly T, Yang W, Chen CS, Reynolds K \& He J 2008 Global burden of obesity in 2005 and projections to 2030. International Journal of Obesity 32 1431-1437. (doi:10.1038/ijo.2008.102)

Kraschnewski JL, Boan J, Esposito J, Sherwood NE, Lehman EB, Kephart DK \& Sciamanna CN 2010 Long-term weight loss maintenance in the United States. International Journal of Obesity 34 1644-1654. (doi:10.1038/ijo.2010.94)

Lebon G, Warne T, Edwards PC, Bennett K, Langmead CJ, Leslie AG \& Tate CG 2011 Agonist-bound adenosine A2A receptor structures reveal common features of GPCR activation. Nature 474 521-525. (doi:10.1038/nature10136)

Lemmens VE, Oenema A, Klepp KI, Henriksen HB \& Brug J 2008 A systematic review of the evidence regarding efficacy of obesity prevention interventions among adults. Obesity Reviews 9 446-455. (doi:10.1111/j.1467-789X.2008.00468.x) 
Mirshahi UL, Still CD, Masker KK, Gerhard GS, Carey DJ \& Mirshahi T 2011 The MC4R(I251L) allele is associated with better metabolic status and more weight loss after gastric bypass surgery. Journal of Clinical Endocrinology and Metabolism 96 E2088-E2096. (doi:10.1210/ jc.2011-1549)

Murakami M \& Kouyama T 2008 Crystal structure of squid rhodopsin. Nature 453 363-367. (doi:10.1038/nature06925)

Nicholson JR, Kohler G, Schaerer F, Senn C, Weyermann P \& Hofbauer KG 2006 Peripheral administration of a melanocortin 4-receptor inverse agonist prevents loss of lean body mass in tumorbearing mice. Journal of Pharmacology and Experimental Therapeutics 317 771-777. (doi:10.1124/jpet.105.097725)

Nijenhuis WA, Oosterom J \& Adan RA $2001 \operatorname{AgRP}(83-132)$ acts as an inverse agonist on the human melanocortin-4 receptor. Molecular Endocrinology 15 164-171. (doi:10.1210/me.15.1.164)

O'Rahilly S, Farooqi IS, Yeo GS \& Challis BG 2003 Minireview: human obesity - lessons from monogenic disorders. Endocrinology 144 3757-3764. (doi:10.1210/en.2003-0373)

Palczewski K, Kumasaka T, Hori T, Behnke CA, Motoshima H, Fox BA, Le Trong I, Teller DC, Okada T, Stenkamp RE et al. 2000 Crystal structure of rhodopsin: a G protein-coupled receptor. Science $\mathbf{2 8 9}$ 739-745. (doi:10.1126/science.289.5480.739)

Park JH, Scheerer P, Hofmann KP, Choe HW \& Ernst OP 2008 Crystal structure of the ligand-free G-protein-coupled receptor opsin. Nature 454 183-187. (doi:10.1038/nature07063)

Pogozheva ID, Chai BX, Lomize AL, Fong TM, Weinberg DH, Nargund RP, Mulholland MW, Gantz I \& Mosberg HI 2005 Interactions of human melanocortin 4 receptor with nonpeptide and peptide agonists. Biochemistry 44 11329-11341. (doi:10.1021/ bi0501840)

Poitout L, Brault V, Sackur C, Bernetiere S, Camara J, Plas P \& Roubert P 2007 Identification of a novel series of benzimidazoles as potent and selective antagonists of the human melanocortin-4 receptor. Bioorganic E Medicinal Chemistry Letters 17 4464-4470. (doi:10.1016/ j.bmcl.2007.06.010)

Proneth B, Xiang Z, Pogozheva ID, Litherland SA, Gorbatyuk OS, Shaw AM, Millard WJ, Mosberg HI \& Haskell-Luevano C 2006 Molecular mechanism of the constitutive activation of the L250Q human melanocortin-4 receptor polymorphism. Chemical Biology $\mathcal{E}$ Drug Design 67 215-229. (doi:10.1111/j.1747-0285.2006.00362.x)

Ramon E, Cordomi A, Bosch L, Zernii EY, Senin II, Manyosa J, Philippov PP, Perez JJ \& Garriga P 2007 Critical role of electrostatic interactions of amino acids at the cytoplasmic region of helices 3 and 6 in rhodopsin conformational properties and activation. Journal of Biological Chemistry 282 14272-14282. (doi:10.1074/jbc. M611091200)

Rasmussen SG, Choi HJ, Rosenbaum DM, Kobilka TS, Thian FS, Edwards PC, Burghammer M, Ratnala VR, Sanishvili R, Fischetti RF et al. 2007 Crystal structure of the human $\beta_{2}$ adrenergic G-proteincoupled receptor. Nature 450 383-387. (doi:10.1038/nature06325)

Rasmussen SG, Choi HJ, Fung JJ, Pardon E, Casarosa P, Chae PS, Devree BT, Rosenbaum DM, Thian FS, Kobilka TS et al. 2011 Structure of a nanobody-stabilized active state of the $\beta_{2}$ adrenoceptor. Nature 469 175-180. (doi:10.1038/nature09648)

Reinehr T, Hebebrand J, Friedel S, Toschke AM, Brumm H, Biebermann H \& Hinney A 2009 Lifestyle intervention in obese children with variations in the melanocortin 4 receptor gene. Obesity 17 382-389. (doi:10.1038/oby.2008.422)

Reiter E, Ahn S, Shukla AK \& Lefkowitz RJ 2012 Molecular mechanism of $\beta$-arrestin-biased agonism at seven-transmembrane receptors. Annual Review of Pharmacology and Toxicology 52 179-197. (doi:10.1146/annurev.pharmtox.010909.105800)

Rosenbaum DM, Cherezov V, Hanson MA, Rasmussen SG, Thian FS, Kobilka TS, Choi HJ, Yao XJ, Weis WI, Stevens RC et al. 2007 GPCR engineering yields high-resolution structural insights into $\beta_{2}$-adrenergic receptor function. Science 318 1266-1273. (doi:10.1126/science.1150609)
Scheerer P, Park JH, Hildebrand PW, Kim YJ, Krauss N, Choe HW, Hofmann KP \& Ernst OP 2008 Crystal structure of opsin in its G-protein-interacting conformation. Nature 455 497-502. (doi:10.1038/nature07330)

Schneider EH, Schnell D, Strasser A, Dove S \& Seifert R 2010 Impact of the DRY motif and the missing "ionic lock" on constitutive activity and G-protein coupling of the human histamine $\mathrm{H} 4$ receptor. Journal of Pharmacology and Experimental Therapeutics 333 382-392. (doi:10.1124/jpet.109.163220)

Srinivasan S, Lubrano-Berthelier C, Govaerts C, Picard F, Santiago P, Conklin BR \& Vaisse C 2004 Constitutive activity of the melanocortin-4 receptor is maintained by its N-terminal domain and plays a role in energy homeostasis in humans. Journal of Clinical Investigation 114 1158-1164.

Stutzmann F, Vatin V, Cauchi S, Morandi A, Jouret B, Landt O, Tounian P, Levy-Marchal C, Buzzetti R, Pinelli L et al. 2007 Nonsynonymous polymorphisms in melanocortin-4 receptor protect against obesity: the two facets of a Janus obesity gene. Human Molecular Genetics 16 1837-1844. (doi:10.1093/hmg/ddm132)

Stutzmann F, Tan K, Vatin V, Dina C, Jouret B, Tichet J, Balkau B, Potoczna N, Horber F, O'Rahilly S et al. 2008 Prevalence of melanocortin-4 receptor deficiency in Europeans and their agedependent penetrance in multigenerational pedigrees. Diabetes $\mathbf{5 7}$ 2511-2518. (doi:10.2337/db08-0153)

Sutton GM, Duos B, Patterson LM \& Berthoud HR 2005 Melanocortinergic modulation of cholecystokinin-induced suppression of feeding through extracellular signal-regulated kinase signaling in rat solitary nucleus. Endocrinology 146 3739-3747. (doi:10.1210/ en.2005-0562)

Tan K, Pogozheva ID, Yeo GS, Hadaschik D, Keogh JM, Haskell-Leuvano C, O'Rahilly S, Mosberg HI \& Farooqi IS 2009 Functional characterization and structural modeling of obesity associated mutations in the melanocortin 4 receptor. Endocrinology 150 114-125. (doi:10.1210/en.2008-0721)

Tao YX 2005 Molecular mechanisms of the neural melanocortin receptor dysfunction in severe early onset obesity. Molecular and Cellular Endocrinology 239 1-14. (doi:10.1016/j.mce.2005.04.012)

Tao YX 2007 Functional characterization of novel melanocortin-3 receptor mutations identified from obese subjects. Biochimica et Biophysica Acta 1772 1167-1174. (doi:10.1016/j.bbadis.2007.09.002)

Tao YX 2008 Constitutive activation of G protein-coupled receptors and diseases: insights into mechanism of activation and therapeutics. Pharmacology E Therapeutics 120 129-148. (doi:10.1016/ j.pharmthera.2008.07.005)

Tao YX 2009 Mutations in melanocortin-4 receptor and human obesity. Progress in Molecular Biology and Translational Science $\mathbf{8 8}$ 173-204. (doi:10.1016/S1877-1173(09)8806-x)

Tao YX 2010 The melanocortin-4 receptor: physiology, pharmacology, and pathophysiology. Endocrine Reviews 31 506-543. (doi:10.1210/ er.2009-0037)

Tao YX \& Segaloff DL 2003 Functional characterization of melanocortin-4 receptor mutations associated with childhood obesity. Endocrinology 144 4544-4551. (doi:10.1210/en.2003-0524)

Tao YX \& Segaloff DL 2005 Functional analyses of melanocortin-4 receptor mutations identified from patients with binge eating disorder and nonobese or obese subjects. Journal of Clinical Endocrinology and Metabolism 90 5632-5638. (doi:10.1210/ jc.2005-0519)

Tao YX, Mizrachi D \& Segaloff DL 2002 Chimeras of the rat and human FSH receptors (FSHRs) identify residues that permit or suppress transmembrane 6 mutation-induced constitutive activation of the FSHR via rearrangements of hydrophobic interactions between helices 6 and 7. Molecular Endocrinology 16 1881-1892. (doi:10.1210/me.2001-0199)

Tao YX, Huang H, Wang ZQ, Yang F, Williams JN \& Nikiforovich GV 2010 Constitutive activity of neural melanocortin receptors. Methods in Enzymology 484 267-279. (doi:10.1016/B978-0-12-381298-8.00014-9) 
Violin JD \& Lefkowitz RJ 2007 -Arrestin-biased ligands at seventransmembrane receptors. Trends in Pharmacological Sciences 28 416-422. (doi:10.1016/j.tips.2007.06.006)

Vongs A, Lynn NM \& Rosenblum CI 2004 Activation of MAP kinase by MC4-R through PI3 kinase. Regulatory Peptides 120 113-118. (doi:10.1016/j.regpep.2004.02.018)

Vos TJ, Caracoti A, Che JL, Dai M, Farrer CA, Forsyth NE, Drabic SV, Horlick RA, Lamppu D, Yowe DL et al. 2004 Identification of 2-[2-[2(5-bromo-2- methoxyphenyl)-ethyl]-3-fluorophenyl]-4,5-dihydro1H-imidazole (ML00253764), a small molecule melanocortin 4 receptor antagonist that effectively reduces tumor-induced weight loss in a mouse model. Journal of Medicinal Chemistry 47 1602-1604. (doi:10.1021/jm034244g)

Wang ZQ \& Tao YX 2011 Functional studies on twenty novel naturally occurring melanocortin-4 receptor mutations. Biochimica et Biophysica Acta 1812 1190-1199. (doi:10.1016/j.bbadis.2011. 06.008)

Wang SX, Fan ZC \& Tao YX 2008 Functions of acidic transmembrane residues in human melanocortin-3 receptor binding and activation. Biochemical Pharmacology 76 520-530. (doi:10.1016/j.bcp.2008. 05.026)

Warne T, Serrano-Vega MJ, BakerJG, Moukhametzianov R, Edwards PC, Henderson R, Leslie AG, Tate CG \& Schertler GF 2008 Structure of a $\beta_{1}$-adrenergic G-protein-coupled receptor. Nature $\mathbf{4 5 4} 486-491$. (doi:10.1038/nature07101)

Wu H, Wacker D, Mileni M, Katritch V, Han GW, Vardy E, Liu W, Thompson AA, Huang XP, Carroll FI et al. 2012 Structure of the human $\kappa$-opioid receptor in complex with JDTic. Nature 485 327-332. (doi:10.1038/nature10939)
Xiang Z, Litherland SA, Sorensen NB, Proneth B, Wood MS, Shaw AM, Millard WJ \& Haskell-Luevano C 2006 Pharmacological characterization of 40 human melanocortin- 4 receptor polymorphisms with the endogenous proopiomelanocortin-derived agonists and the agouti-related protein (AGRP) antagonist. Biochemistry 45 7277-7288. (doi:10.1021/bi0600300)

Xiang Z, Pogozheva ID, Sorenson NB, Wilczynski AM, Holder JR, Litherland SA, Millard WJ, Mosberg HI \& Haskell-Luevano C 2007 Peptide and small molecules rescue the functional activity and agonist potency of dysfunctional human melanocortin-4 receptor polymorphisms. Biochemistry 46 8273-8287. (doi:10.1021/ bi7007382)

Xu F, Wu H, Katritch V, Han GW, Jacobson KA, Gao ZG, Cherezov V \& Stevens RC 2011 Structure of an agonist-bound human A2A adenosine receptor. Science 332 322-327. (doi:10.1126/science. 1202793)

Yang F \& Tao YX 2012 Functional characterization of nine novel naturally occurring human melanocortin-3 receptor mutations. Biochimica et Biophysica Acta 1822 1752-1761. (doi:10.1016/j.bbadis. 2012.07.017)

Yang YK, Fong TM, Dickinson CJ, Mao C, Li JY, Tota MR, Mosley R, Van Der Ploeg LH \& Gantz I 2000 Molecular determinants of ligand binding to the human melanocortin-4 receptor. Biochemistry 39 14900-14911. (doi:10.1021/bi001684q)

Received in final form 18 September 2012

Accepted 26 September 2012

Made available online as an Accepted Preprint 26 September 2012 